\title{
High Risk HPV E6/E7 Oncoprotein Expression in Women with High Grade Squamous Intraepithelial Lesion
}

\section{Expressão de oncoproteinas E6/e7 do HPV de alto risco em Mulheres com Lesão Intraepitelial Escamosa de alto grau}

\author{
Ricardo Arraes de Alencar Ximenes ${ }^{6}$ \\ ${ }^{1}$ Gynecology and Obstetric Department, Universidade Federal de \\ Pernambuco - UFPE, Recife, PE, Brazil \\ ${ }^{2}$ Gynecology and Obstetric Department, Universidade Federal do Rio \\ Grande do Norte, Natal, RN, Brazil \\ ${ }^{3}$ Gynecology and Obstetric Department, Universidade Federal de São \\ Paulo, São Paulo, SP, Brazil \\ ${ }^{4}$ Gynecology and Obstetric Department, Universidade Federal do \\ Ceará, Fortaleza, CE, Brazil \\ 5 Biochemistry Department, UFPE, Recife, PE, Brazil \\ ${ }^{6}$ Tropical Medicine Department, UFPE, Recife, PE, Brazil
}

Jefferson Elias Cordeiro Valença ${ }^{1}$ Ana Katherine Gonçalves ${ }^{2}$ Ismael Dale Cotrim Guerreiro da Silva ${ }^{3}$ José Eleutério Junior ${ }^{4}$ Terezinha Tenório da Silva ${ }^{1}$ Danyelly Bruneska ${ }^{5}$

\begin{abstract}
Address for correspondence Jefferson Elias Cordeiro Valença, MD, PhD, Hospital das Clínicas da UFPE, Av. Prof. Moraes Rego, s/n, Bl. A, Cidade Universitária, Recife, PE, Brazil 50670-901

(e-mail: jeffersonvalenca25@hotmail.com).
\end{abstract}

Rev Bras Ginecol Obstet 2016;38:154-159.

\begin{abstract}
Purpose To correlate the expression of high-risk HPV E6 mRNA with pap smear, colposcopy, and biopsy results in women with high grade squamous intraepithelial lesion (HSIL).

Methods A cross-sectional study was performed on women referred for primary care services after cytological diagnosis of HSIL. We evaluated the expression of E6/E7 mRNA of HPV types $16,18,31,33$, and 45 and correlated the results with those of Pap smear, colposcopy, and biopsy. For amplification/detection of mRNA E6 / E7 we used NucliSENSEasyQ kit to detect HPV mRNA by polymerase chain reaction with primers/ probes for HPV types $16,18,31,33$, and 45.

Results Out of 128 valid tests, the results of 30 (23.4\%) tests were negative and 98 (70\%) tests were positive. Only one type of HPV was detected in $87.7 \%$ of the E6/E7

Keywords

- colposcopy

- HPV

- mRNA

- Pap smear

- women mRNA positive cases. HPV16 was detected in $61.2 \%$ of the cases, followed by HPV33 (26.5\%), HPV31 (17.3\%), HPV18 (10\%), and HPV45 (4.08\%). Pap smear tests revealed that the E6/E7 test was positive in 107 (83.8\%) women with atypical squamous cells high grade (ASC-H), HSIL, or higher. The E6/E7 test was positive in 69 (57.5\%) specimens presenting negative cytology results. When analyzing the association with colposcopy results, the frequency of positive E6/E7 results increased with the severity of the injury, ranging from $57.1 \%$ in women without colposcopy-detected injury to $86.5 \%$ in those
\end{abstract}

received

September 21, 2015 accepted

December 17, 2015

published online

March 21, 2016
DOI http://dx.doi.org/ $10.1055 / \mathrm{s}-0036-1580713$. ISSN $0100-7203$.
Copyright $\odot 2016$ by Thieme Publicações License terms Ltda, Rio de Janeiro, Brazil
(1) $\Theta \circledast$ 


\section{Resumo \\ Palavras-chave \\ - RNAm \\ - HPV \\ - Papanicolau \\ - colposcopia \\ - mulheres \\ Objetivo Correlacionar a expressão mRNAE6/E7 do HPV de alto risco com os exames de Papanicolau, colposcopia e biópsia em mulheres com lesão intraepitelial escamosa de alto grau (HSIL). \\ Métodos Estudo transversal com mulheres encaminhadas aos serviços de atenção primária com diagnóstico citológico de HSIL. Foi avaliada a expressão do mRNAE6/E7 dos tipos de HPV 16,18,31,33 e 45, correlacionando-se a expressão com os exames de Papanicolau, colposcopia e biópsia. Para a amplificação/detecção de mRNA de E6/E7 foi usado o kit NucliSENS EasyQ ${ }^{\circledR}$ HPV que detecta mRNA do HPV por meio da reação em cadeia da polimerase com primers/probes HPV dos tipos 16, 18, 31, 33 e 45. \\ Resultados Foram obtidos 128 testes válidos. Destes: 30 (23,4\%) foram negativos e 98 (70\%) dos testes foram positivos. Foi encontrado apenas um tipo de HPV em 87,7\% dos positivos. O HPV16 foi o mais encontrado em $61,2 \%$, seguido pelos HPV33 (26,5\%); HPV31 (17,34\%); HPV 18 (10,0\%) e HPV (45 4,0\%). Quanto ao exame de Papanicolau, o teste E6/E7 foi positivo em 107 (83,8\%) das mulheres com ASC-H, HSIL ou superior, enquanto em citologia negativa foi encontrado um resultado positivo em 69 (57,5\%) colposcopia. A frequência de teste E6/E7 positivo aumentou com a gravidade da lesão, detectada na colposcopia variando de 57,1\% em mulheres sem lesão identificada em colposcopia até 86,5\% naqueles com achado de colposcopia de grau maior. Das 111 mulheres que se submeteram a biópsia e o teste E6/E7, o teste foi positivo em $84,7 \%$ das que apresentaram lesão igual ou superior a NIC 2 (neoplasia intraepitelial cervical) e $41,2 \%$ daqueles com biópsia negativa. \\ Conclusões A expressão de E6, E7 RNAm ocorreu com maior frequência em lesões de alto grau citológica e em casos com biópsias de NIC2 ou maior.}

with higher levels of colposcopy findings. Of the 111 women who underwent biopsy and E6/E7 testing, the E6/E7 test was positive in $84.7 \%$ of the women who presented with lesions of cervical intraepithelial neoplasia (CIN) grade 2 or higher. Finally, $41.2 \%$ of women with a negative biopsy presented a positive E6/E7 test.

Conclusions E6/E7 mRNA expression was higher in women with HSIL and CIN grade 2 or higher.

\section{Introduction}

Frequent occurrence of cervical cancer has been reported despite the use of cytological cervical screening (Papanicolau test). ${ }^{1}$ Persistent infection by high-risk human papilloma virus (HPV) is an important factor associated with this neoplasia, ${ }^{2}$ which displays well-defined precursor lesions that may become invasive after variable periods. Thus, if the precursor lesions are detected at the initial or pre-invasive stages, the progression of cervical cancer can be interrupted. ${ }^{3}$

Oncotic cytology, introduced in 1943, is the most widespread secondary prevention program ever introduced for the screening of cervical cancer. However, the sensitivity is limited and varies between 30 and $87 \%$ in differentlaboratories. ${ }^{4}$ Recent studies defended its use in conjunction with molecular tests to detect HPV DNA, with a substantial increase in sensitivity and improved reproducibility. ${ }^{5,6}$
Nevertheless, the detection of DNA only indicates the presence of $\mathrm{HPV}^{7}$ and few infections are associated with lesions that progress toward malignancy. For this to occur there should be an overexpression of the E6 and E7 genes from the genome of an integrated HPV. Thus, the E6 and E7 transcripts could be useful as markers of disease progression. $^{8}$ The detection of the HPV E6/E7 messenger RNA (mRNA) allows the monitoring of the oncogenic activity of the virus, by detecting the active transcription of viral DNA. ${ }^{7}$

The levels of E6/E7 mRNA increase according to the severity of the lesion. ${ }^{8,9}$ Thus, E6/E7 mRNA detection can have a high prognostic value and can improve the specificity and positive predictive value when compared with the HPVDNA test. According to a previous study, E6/E7 HPV-mRNA is detected in more than $90 \%$ of the cervical intraepithelial lesion CIN grades 2 and 3, or cervical cancer. ${ }^{7}$ Thus, the objective of this study was to evaluate the expression of E6/ E7 mRNA of HPV types 16, 18, 31, 33, and 45 among women with atypical cytological diagnosis, and correlate E6/E7 
mRNA expression with the results of colposcopy-guided biopsy.

\section{Methods}

A prospective cross-sectional study was conducted between July 2010 and November 2013. Women who attended the Department of Pathology of the Lower Genital Tract and Colposcopy of the Gynecology Department in the Hospital das Clínicas of the Federal University of Pernambuco (UFPE) - Brazil were included. All women referred to primary care services were cytologically diagnosed with HSIL. After being informed about the objectives of the study, women who agreed to participate in the study signed an informed consent form and answered a standard questionnaire. The study was approved by the Ethics Committee in Research with Humans (CEPSH) of the CCS (Health Sciences Center), UFPE.

The exclusion criteria were pregnancy, positive serology for human immunodeficiency virus (HIV), and use of immunosuppressants.

After the introduction of the speculum, a new ecto and endocervical harvest was performed for smear cytology (CO) by the conventional method, using an Ayre spatula and cytobrush. The cytological report was based on the nomenclature of the Bethesda System. ${ }^{10}$

The brush used to collect samples for oncotic cytology, was used to harvest new cervical material with the bristle side placed in a $2 \mathrm{~mL}$ Eppendorf ${ }^{\mathrm{TM}}$ tube containing $1.5 \mathrm{~mL}$ of buffered methanol, and the cervical samples were subsequently stored at $-20^{\circ} \mathrm{C}$ until the HPV RNA extraction. The amplification and detection of the E6/E7 mRNA was performed with the NucliSENSEasyQ ${ }^{\circledR}$ HPV kit (BIOMÉRIEUX, Marcy l'Etoile, France), using the polymerase chain reaction (PCR) with primers/probes for HPV types 16, 18, 31, 33, and 45 . In addition to the negative and positive controls, all reactions were processed with the mRNA of the U1A gene as an internal control, to ensure the integrity of the RNA and the reagents. The preparation of the reagent mix and addition of the samples followed the protocol recommended by the manufacturer. The protocol was concluded by placing the plate in the NucliSENSEasyQ ${ }^{\circledR}$ equipment for the mRNA detection and amplification.

After collecting the materials for oncotic cytology and the E6/E7 test, colposcopy examination was performed and findings were described according to the nomenclature of the International Federation of Colposcopy and Cervical Pathology. ${ }^{11}$ In cases of suspected lesion, the biopsy was

Table 1 E6/E7 test results according to the epidemiological characteristics of women referred to a primary care service with Pap test compatible with high-grade squamous intraepithelial lesion (HSIL)

\begin{tabular}{|l|l|l|l|}
\hline \multirow{2}{*}{ Variables } & \multicolumn{2}{l}{ Test Result } & \multirow{2}{*}{-value } \\
\cline { 2 - 3 } & $\begin{array}{l}\text { Positive } \\
\text { Mean } \pm \text { SD }\end{array}$ & $\begin{array}{l}\text { Negative } \\
\text { Mean } \pm \text { SD }\end{array}$ & \multicolumn{2}{l}{$0.00^{* * *}$} \\
\hline Age & $35.3 \pm 11.0$ & $41.9 \pm 11.8$ & $0.06^{*}$ \\
\hline Age, first sexual intercourse & $16.0 \pm 2.9$ & $17.3 \pm 4.3$ & $0.09^{*}$ \\
\hline Number of pregnancies & $3.4 \pm 2.8$ & $4.5 \pm 3.4$ & 0.29 \\
\hline Number of partners & $3.9 \pm 2.8$ & $3.3 \pm 2.7$ & $0.01^{* * *}$ \\
\hline Age at first delivery & $17.5 \pm 4.8$ & $20.0 \pm 4.5$ & \\
\hline & $\mathbf{n}(\%)$ & $\mathbf{n}(\%)$ & \\
\hline Smoking & & & $0.73^{* *}$ \\
\hline Never & $69(70.4)$ & $21(70.0)$ & \\
\hline Yes & $23(23.5)$ & $6(20.0)$ & \\
\hline Ex-smokers & $6(6.1)$ & $3(10.0)$ & \\
\hline Alcohol & & & $0.1^{* *}$ \\
\hline Abstinent & $52(53.1)$ & $21(70.0)$ & \\
\hline Not totally abstinent & $46(46.9)$ & $9(30.0)$ & $0.19^{*}$ \\
\hline Number of preventive measures & $1.5 \pm 1.2$ & $1.2 \pm 1.3$ & \\
\hline Use of condom & & & $0.16^{* *}$ \\
\hline Never Used & $24(24.5)$ & $12(40.0)$ & \\
\hline Sometimes & $31(31.6)$ & $9(30.0)$ & \\
\hline Always & $10(10.2)$ & 0 & \\
\hline Already used, but not currently & $33(33.7)$ & $9(30.0)$ & \\
\hline
\end{tabular}

Abbreviation: SD, standard deviation.

${ }^{*}, t$-test, ${ }^{* *}$, chi-square test, ${ }^{* * *}$, Mann-Whitney Test. 
performed with Gaylor-Medina forceps. The fragments were placed in a vial with $10 \%$ buffered formalin and sent for histopathological examination.

In the pathology laboratory, the fragments were processed and embedded in paraffin and subsequently sliced to obtain 5$\mu \mathrm{m}$-sections, which were stained with hematoxylin-eosin and analyzed by optical microscopy. The reports were in accordance with the international nomenclature of pathology for cervical intraepithelial neoplasia and cervical cancer. ${ }^{12}$

The responses to the questionnaire and the results of the examinations and procedures were entered in the EPI-INFO program. The chi-square test and the chi-square test for trend were used to compare categorical variables and the $t$-test for comparison of means. The Mann-Whitney test was used for the variables that did not present a normal distribution. The differences were considered statistically significant when $p<0.05$. All analyzes were performed using the Stata (version 10.1) statistical software.

\section{Results}

Samples were obtained from the 140 women presenting with HSIL to detect E6/E7 mRNA of HPV types 16, 18, 31, 33, and 45 . Out of all cases, $8.6 \%$ (12/140) presented invalid data, $21.4 \%$ (30/140) were negative, and 70\% (98/140) positive.

Among the 128 valid tests, $23.4 \%$ (30/128) were negative for E6/E7 mRNA. Among the 98 positive cases, only one type of HPV was detected in $87.7 \%$ of the samples (86/98).

The comparison of socio-demographic characteristics between the patients with negative and positive results showed no significant difference (-Table $\mathbf{1}$ ).

HPV16 was the most common type detected, 61.2\% (60/ 98), followed by HPV33, 26.5\% (26/98), HPV31, 17.3\% (17/98), HPV18, 5.1\% (5/98), and HPV45, 4.1\% (4/98).

Among the $12.2 \%$ (12/98) cases presenting multiple infections, the most frequently detected type was also HPV16 (83.3\%), followed by HPV33 (75\%), HPV45 (25\%), HPV31 (16.7\%), and HPV18 (8.3\%).

The HPV18 type was detected in one biopsy displaying adenocarcinoma, in the only cytology that displayed adeno- carcinoma in-situ (AIS), and in one of the two cytology with adenocarcinoma; in the other cytology, HPV16 was identified.

When the cytology was repeated, the following results were observed: unsatisfactory, two (1.4\%); negative, 23 (16.4\%); atypical squamous cells of undetermined significance (ASC-US), eight (5.7\%); low-grade squamous intraepithelial lesion (LSIL), 23 (16.4\%); atypical squamous cells in which HSIL cannot be excluded (ASC-H), 6 (4.3\%); HSIL, 70 (50.0\%); HSIL without exclusion of microinvasion, one (0.7\%); squamous cancer, four (2.9\%); atypical squamous cells, one (0.7\%); adenocarcinoma, two (1.4\%).

The E6/E7 test was positive in $83.8 \%$ of women with ASC$\mathrm{H}$, HSIL, or greater, while, in women presenting a negative cytology, E6/E7 test was positive in $57.9 \%$ of the cases (-Table 2).

Of the 140 colposcopy examinations, $11.4 \%$ of the cases presented no lesion and $6.3 \%$ presented unspecific or miscellaneous changes. Abnormal low-grade colposcopy findings were identified in $42.9 \%$ of the cases and higher gradecolposcopy findings in $39.3 \%$. The squamocolumnar junction was not visualized in $37.9 \%$ of the cases.

Among the 128 women who were subjected to colposcopy and for which the E6/E7 test was valid, $82 \%$ presented abnormal colposcopy findings and $18 \%$ showed no lesion or nonspecific lesion. The frequency of E6/E7 positivity ranged from $57.1 \%$ in women without colposcopy-detected lesions and up to $86.5 \%$ in those with higher-grade colposcopy-detected lesions.

Histopathological examination of 124 biopsy samples showed the following results: negative, 13.6\%; CIN1, 15.7\%; CIN2, 19.3\%; CIN3, 35.7\%; microinvasion, 0.7\%; squamous cancer, $0.7 \%$; adenocarcinoma, $0.7 \%$; CIN ungraded, $1.4 \%$; and inadequate sample, $0.7 \%$.

Among the 111 women who underwent a biopsy and presented a valid E6/E7 test, the E6/E7 test was positive in $84.72 \%$ of the women presenting with neoplasia equal or more serious than CIN2 and in $41.18 \%$ of women presenting with negative biopsy. The sensitivity of the test for CIN2 or higher was $84.7 \%$, while the specificity was $30.8 \%$. The positive predictive value was $69.3 \%$. The negative

Table 2 Relationship between colposcopy-detected findings and positivity of HPV E6/E7 mRNA test in women referred to a primary care service with a Pap test compatible with high-grade squamous intraepithelial lesion (HSIL)

\begin{tabular}{|c|c|c|c|c|c|c|}
\hline \multirow[t]{3}{*}{ Cytology } & \multicolumn{4}{|c|}{ Test Result } & \multirow{2}{*}{\multicolumn{2}{|c|}{ Total }} \\
\hline & \multicolumn{2}{|c|}{ Positive } & \multicolumn{2}{|c|}{ Negative } & & \\
\hline & $\mathrm{N}$ & $\%$ & $\mathrm{~N}$ & $\%$ & $\mathrm{~N}$ & $\%$ \\
\hline Negative & 11 & 57.8 & 8 & 42.1 & 19 & 15.4 \\
\hline ASC-US / LSIL & 22 & 73.3 & 8 & 26.6 & 30 & 24.3 \\
\hline $\mathrm{ASC}-\mathrm{H} / \geq \mathrm{HSIL}$ & 62 & 83.7 & 12 & 16.2 & 74 & 60.1 \\
\hline Total & 95 & 77.2 & 28 & 22.7 & 123 & 100.0 \\
\hline
\end{tabular}

Abbreviation: ASC-H, atypical squamous cells of undetermined significance in which high-grade squamous intraepithelial lesion cannot be excluded; ASC-US, atypical squamous cells of undetermined significance possibly non-neoplastic; HSIL, high-grade squamous intraepithelial lesion; LSIL, lowgrade squamous intraepithelial lesion.

$P$ value $=0.02127 ; \mathrm{x}^{2}$ trend value $=5.30481$.

Note: Two results of unsatisfactory cytology and three of glandular lesions were not included. Additionally, invalid E6/E7 tests were not included. 
Table 3 E6/E7 mRNA test results according to histopathological results in women referred to a primary care service with a Pap test compatible with high-grade squamous intraepithelial lesion (HSIL)

\begin{tabular}{|l|l|l|l|}
\hline E6/E7 Test & $\geq$ CIN2 (\%) & $<$ CIN2 (\%) & Total (\%) \\
\hline Positive & $61(69.3)$ & $27(30.6)$ & $88(79.2)$ \\
\hline Negative & $11(47.8)$ & $12(52.1)$ & $23(20.7)$ \\
\hline Total & $72(64.8)$ & $39(35.1)$ & $111(100.0)$ \\
\hline
\end{tabular}

Accuracy = 65.7; Negative Predictive Value = 52.2 (31.7-72.6); Positive Predictive Value = 69.3 (59.7-78.9); Sensitivity = 84.7 (76.4-93.0); Specificity $=30.8(16.2-45.2)$.

predictive value was $52.2 \%$, and the accuracy was $65.7 \%$ (-Table 3).

\section{Discussion}

The E6/E7 mRNA test of HPV types 16, 18, 31, 33, and 45 was positive in $76 \%$ of women who presented with a cytological diagnosis of HSIL and in $83 \%$ of the women whose diagnosis was confirmed by new cytology tests performed for the study. There was an increase in the percentage of positivity proportional to the grading of the cytological and histopathological changes. HPV16 was detected with higher frequency, followed by HPV $33,31,18$, and 45 . Such findings are similar to those of Dixon et al, ${ }^{13}$ who observed positive results in $80 \%$ of HSIL samples. The cytological, colposcopic, and histological correlations confirmed the observations of other authors. ${ }^{8,9,14}$

Among the cases with negative cytology, ASC-H cases had $57.9 \%$ with an E6/E7 positive test, while the $\geq$ HSIL cases had 83.8\%. Cases in which the cytology was negative and the E6/ E7 test was positive suggest the possibility of false negative cytology or viral integration without morphological lesions. ${ }^{15,16}$ According to Li and Kristensen, ${ }^{7}$ when the cytology examination reveals negative result and the E6/E7 test is positive, one could consider a latent infection. Negative E6/ E7 tests observed in women with high-grade colpocytologic findings could be due to the presence of other types of HPV, not screened in this study. ${ }^{7}$ However, previous studies suggest caution in these cases due to the higher risk of other important findings in the follow-up. ${ }^{17}$

The HPV E6/E7 mRNA test was positive in $85 \%$ of the biopsies with CIN2 or higher, in agreement with the variation described by others, who detected HPV E6/E7 mRNA between $63 \%$ and $92 \%$ of CIN2, 3, or cervical cancer. ${ }^{7,18,19}$ Such findings demonstrated an interesting sensitivity for the identification of high-grade and invasive lesions and are in agreement with the literature. ${ }^{20}$

In this study, HPV16 was identified as the most frequent type (61\%), in agreement with other studies, taking into account the regional variability of other types. ${ }^{21-26}$ The HPV18 type, related with glandular lesions, ${ }^{27-29}$ was associated with confirmed adenocarcinoma.

The performance of the test was studied in relation to CIN2 or higher grade, considering the histopathologic diagnosis as the gold standard. ${ }^{30,31}$ The sensitivity of the E6/E7 test, $84 \%$ for CIN2/3, was greater than that observed by
Jeantet et $\mathrm{al}^{32}$ who determined a $73.6 \%$ sensitivity for CIN2 and $82.2 \%$ for CIN3. These numbers were lower than that obtained by Pierry et al, ${ }^{33}$ who observed a $89 \%$ sensitivity for CIN2 and $100 \%$ for CIN3. These numbers led some researchers to suggest the use of the E6/E7 test as a screening test in cases with abnormal cytology or HPV-DNA tests. ${ }^{34}$

Given the results, one can conclude that the expression of E6/E7 mRNA was observed the most among patients with HSIL and CIN2 or higher grades in the biopsy, which suggests an important correlation that could be inferred as a prognostic factor. Nevertheless, despite the tendency to use E6/E7 mRNA screening test due to its prognostic value, new and more well-designed studies are needed to confirm the effectiveness of this test.

\section{Referências}

1 Fitch MI, Greenberg M, Cava M, Spaner D, Taylor K. Exploring the barriers to cervical screening in an urban Canadian setting. Cancer Nurs 1998;21(6):441-449

2 zurHausen H. Papillomaviruses in the causation of human cancers a brief historical account. Virology 2009;384(2):260-265

3 Boicea A, Pătraşcu A, Surlin V, Iliescu D, Schenker M, Chiuțu L. Correlations between colposcopy and histologic results from colposcopically directed biopsy in cervical precancerous lesions. Rom J MorpholEmbryol 2012;53(3, Suppl)735-741

4 Nanda K, McCrory DC, Myers ER, et al. Accuracy of the Papanicolaou test in screening for and follow-up of cervical cytologic abnormalities: a systematic review. Ann Intern Med 2000;132(10):810-819

5 International Agency for Research on Cancer Working Group on the Evaluation of Carcinogenic Risks to Humans [Internet]. Human papillomaviruses. Lyon: IARC; 2005. (IARC monographs on evaluation of carcinogenic risks to humans, 90) [cited 2015 Jul 19]. Available from: http://monographs.iarc.fr/ENG/Monographs/ vol90/mono90.pdf

6 Wright TC Jr. HPV DNA testing for cervical cancer screening. FIGO 26th Annual Report on the Results of Treatment in Gynecological Cancer. Int J GynaecolObstet 2006;95(Suppl 1): S239-S246

7 Lie AK, Kristensen G. Human papillomavirus E6/E7 mRNA testing as a predictive marker for cervical carcinoma. Expert Rev MolDiagn 2008;8(4):405-415

8 Cattani P, Zannoni GF, Ricci C, et al. Clinical performance of human papillomavirus E6 and E7 mRNA testing for high-grade lesions of the cervix. J ClinMicrobiol 2009;47(12):3895-3901

9 Argyri E, Tsimplaki E, Daskalopoulou D, et al. E6/E7 mRNA expression of high-risk HPV types in 849 Greek women. Anticancer Res 2013;33(9):4007-4011 
10 Sellors JW, Sankaranarayanan R. Colposcopy and treatment of cervical intraepithelial neoplasia: a beginner's manual. Lyon: IARC; 2004. Chapter 1: An introduction to the anatomy of the uterine cervix [cited 2015 Jul 19]. Available from: <http://screening.iarc.fr/doc/colpochapter01.pdf >

11 International Federation for Cervical Pathology and Colposcopy [Internet]. IFCPC colposcopic terminology of the cervix. 2011 [cited 2014 May 06]. Available from: <http://www.ifcpc.org/ images/docs/nomenclature7-11.pdf >

12 Sellors JW, Sankaranarayanan R. Colposcopy and treatment of cervical intraepithelial neoplasia: a beginner's manual. Lyon: IARC; 2004 [cited 2015 Jul 19]. Chapter 2: Introduction to cervical intraepithelial neoplasia (CIN). Available from: $<$ http://screening. iarc.fr/doc/colpochapter02.pdf>

13 Dixon EP, King LM, Adams MD, et al. Isolation of RNA from residual BD SurePath liquid-based cytology specimens and detection of HPV E6/E7 mRNA using the PreTectt HPV-Proofer assay. J Virol Methods 2008;154(1-2):220-222

14 Galarowicz B, Jach R, Kidzierska J, et al. The role of mRNA E6/E7 HPV high oncogenic risk expression in colposcopy of cervical intraepithelial neoplasia (CIN). PrzeglLek 2012;69(9):651-657

15 Cernescu EC, Anton G, Ruță S, Cernescu C. The effectiveness of cytological rescreening in the reduction of false negative/ positive Pap reports. Roum Arch MicrobiolImmunol 2013; 72(2):93-104

16 Poomtavorn Y, Himakhun W, Suwannarurk K, Thaweekul Y, Maireang K. Cytohistologic discrepancy of high-grade squamous intraepithelial lesions in Papanicolaou smears. Asian Pac J Cancer Prev 2013;14(1):599-602

17 Giorgi Rossi P, Benevolo M, Vocaturo A, et al. Prognostic value of HPV E6/E7 mRNA assay in women with negative colposcopy or CIN1 histology result: a follow-up study. PLoS ONE 2013;8(2): e57600

18 Massad LS, Einstein MH, Huh WK, et al; 2012 ASCCP Consensus Guidelines Conference. 2012 updated consensus guidelines for the management of abnormal cervical cancer screening tests and cancer precursors. J Low Genit Tract Dis 2013;17(5, Suppl 1): S1-S27

19 Halfon P, Benmoura D, Agostini A, et al. Relevance of HPV mRNA detection in a population of ASCUS plus women using the NucliSENSEasyQ HPV assay. J ClinVirol 2010;47(2):177-181

20 Reid JL, Wright TC Jr, Stoler MH, et al. Human papillomavirus oncogenic mRNA testing for cervical cancer screening: baseline and longitudinal results from the CLEAR study. Am J ClinPathol 2015;144(3):473-483

21 Kraus I, Molden T, Ernø LE, Skomedal H, Karlsen F, Hagmar B. Human papillomavirus oncogenic expression in the dysplastic portio; an investigation of biopsies from 190 cervical cones. $\mathrm{Br} \mathrm{J}$ Cancer 2004;90(7):1407-1413
22 Muñoz N, Bosch FX, Castellsagué X, et al. Against which human papillomavirus types shall we vaccinate and screen? The international perspective. Int J Cancer 2004;111(2):278-285

23 Ali-Risasi C, Verdonck K, Padalko E, Vanden Broeck D, Praet M. Prevalence and risk factors for cancer of the uterine cervix among women living in Kinshasa, the Democratic Republic of the Congo: a cross-sectional study. Infect Agent Cancer 2015;10:20

24 de Mendonça VG, Guimarães MJ, de Lima Filho JL, et al. [Human papillomavirus cervical infection: viral genotyping and risk factors for high-grade squamous intraepithelial lesion and cervix cancer]. Rev Bras GinecolObstet 2010;32(10):476-485Portuguese

25 Kirschner B, Schledermann D, Holl K, et al. HPV-genotypes in high-grade intraepithelial cervical lesions in Danish women. ActaObstetGynecolScand 2013;92(9):1032-1040

26 Mu-Mu-Shwe, Harano T, Okada S, et al. Prevalence of high-risk human papillomavirus (HR-HPV) infection among women with normal and abnormal cervical cytology in Myanmar. Acta Med Okayama 2014;68(2):79-87

27 Molden T, Kraus I, Karlsen F, Skomedal H, Nygård JF, Hagmar B. Comparison of human papillomavirus messenger RNA and DNA detection: a cross-sectional study of 4,136 women $>30$ years of age with a 2-year follow-up of high-grade squamous intraepithelial lesion. Cancer Epidemiol Biomarkers Prev 2005;14(2):367-372

28 Rabelo-Santos SH, Derchain SF, Villa LL, et al. Human papillomavirus-specific genotypes in cervical lesions of women referred for smears with atypical glandular cells or adenocarcinoma in situ. Int J GynecolPathol 2009;28(3):272-278

29 Kim JY, Nam BH, Lee JA. Is human papillomavirus genotype an influencing factor on radiotherapy outcome? Ambiguity caused by an association of HPV 18 genotype and adenocarcinoma histology. J GynecolOncol 2011;22(1):32-38

30 Andersson S, Mints M, Wilander E. Results of cytology and highrisk human papillomavirus testing in females with cervical adenocarcinoma in situ. OncolLett 2013;6(1):215-219

31 Aidé S, Almeida G, Val I, Vespa Junior N, Campaner AR. Neoplasia intraepitalial cervical. DST J Bras Doenças Sex Transm 2009;21(4): 166-170

32 Jeantet D, Schwarzmann F, Tromp J, et al. NucliSENSEasyQ HPV v1 test - Testing for oncogenic activity of human papillomaviruses. J ClinVirol 2009;45(Suppl 1):S29-S37

33 Pierry D, Weiss G, Lack B, Chen V, Fusco J. Intracellular human papillomavirus E6, E7 mRNA quantification predicts CIN 2+ in cervical biopsies better than Papanicolaou screening for women regardless of age. Arch Pathol Lab Med 2012;136(8):956-960

34 Persson M, Elfström KM, BrismarWendel S, Weiderpass E, Andersson S. Triage of HR-HPV positive women with minor cytological abnormalities: a comparison of mRNA testing, HPV DNA testing, and repeat cytology using a 4-year follow-up of a populationbased study. PLoS ONE 2014;9(2):e90023 